także rodzin zmarlych profesorów polskich szkół akademickich. W razie rozwiązania fundacji majątek jej miał przejść na własność Uniwersytetu Poznańskiego, a gdyby i to było niemożliwe - na rzecz państwa polskiego. Pierwszym kuratorem fundacji, a także wykonawcą testamentu Święcickiego został ówczesny prezydent Poznania Cyryl Ratajski ${ }^{33}$. Pomagać miał mu we wszystkich pracach A. Wrzosek.

Ten ostatni był nie tylko współpracownikiem i powiernikiem Święcickiego. Był przede wszystkim jego przyjacielem i archiwista pamiatek, jakie po pierwszym rektorze UP pozostały ${ }^{34}$. A. Wrzosek pozostawił w swojej spuściźnie wspomnienia o rektorze, w których napisal: „Brał serdeczny udział w każdym nieszczęściu, jakie spotkało któregokolwiek z profesorów lub kogoś z ich rodzin. Zabiegał również bardzo o pomoc dla młodzieży pod wszelkimi postaciami. Bez przesady rzec można, że był ojcem dla profesorów i młodzieży uniwersyteckiej" 35. A mimo to, jak utrzymuje A. Wrzosek, taki człowiek miał przeciwników w gronie profesorskim. Opozycji nie zawsze odpowiadal styl zarządzania uczelnią. Było to źródłem troski, a czasami i łez twórcy UP. Kolejną jego zaletą było to, że „potrafił się jednak rychło opanować i być zarówno dla przychylnych mu, jak i przeciwników uśmiechniętym, życzliwym, do usług gotowym (...)"36. Nigdy nie zawiedli go studenci, obrali go nawet na członka honorowego Towarzystwa Studentów Uniwersytetu Poznańskiego „Bratnia Pomoc”. Dlatego dla młodzieży miał Święcicki zawsze ciepłe słowa, taki prawdziwy testament: „Dusza narodu przeto wzywa Cię młody żołnierzu-bohaterze, słuchaczu naszej Wszechnicy na nowy bój, na nowe zbrojenia, zbrojenia ducha, na stoczenie zasadniczej bitwy między dzisiejszym szatanem zamętu, rozstroju, a cichym nieujawnionym, wewnętrznym Aniołem. Macierz Polska wzywa Was, chlubo nasza, nadziejo nasza, na potykanie się ostateczne, a stawką tego mocowania jest: być albo nie być. Albo żyć $w$ chwale, dzierżac krzepko sztandar Polski obok wszystkich wielkich ludów Europy, albo... nie chcę kończyć" ${ }^{37}$.

Heliodor Święcicki zmarł w Poznaniu 10 (12) października 1923 roku, mając 69 lat. Nekrologi ukazały się we wszystkich najważniejszych poznańskich gazetach ${ }^{38}$. „Dziennik Poznański” żegnajac pierwszego rektora napisał: „odchodzi czlowiek wielkiego serca, duszy wspaniałej i potężnej woli, opuszcza opiekun najtroskliwszy umiłowane dzieła swoje..." ${ }^{39}$.

\title{
Przed dwusetna rocznicą powstania Seminarium Nauczycielskiego Józefa Jeziorowskiego w Poznaniu
}

Wkrótce minie dwusetna rocznica powstania pierwszego nowoczesnego, odwołującego się między innymi do wzorców Jana Henryka Pestalozziego, zakładu kształcącego i wychowującego nauczycieli szkół elementarnych na ziemiach polskich - Seminarium Nauczycielskiego Józefa Jeziorowskiego

${ }^{33}$ W materiałach prof. H. Święcickiego (P-III - 85/7) przechowywanych w APAN Oddz w Poznaniu znaleźć można liczne rysunki, przedstawiajace rozmieszczenie poszczególnych budynków Wydziału Lekarskiego.

${ }^{34}$ C. Ratajski, Sprawozdanie kuratora fundacji ,Nauka i Praca" im. Rektora Heliodora Święcickiego za czas od 4.X.1923 do 30.VI.1938, Poznań 1946.

${ }_{35}$ W APAN Oddz. w Poznaniu do dziś znajduja się, jako część spuścizny H. Święcickiego, przedmioty: notesy, stetoskop, ołówek i biret rektorski.

${ }_{36}$ A. Wrzosek, Wspomnienia o ludziach, których znatem: Heliodor Święcicki (wyboru dokonała, wstępem i przypisami opatrzyla A. Marciniak), „Kronika Wielkopolski” 1994, nr 1, s. 85.

${ }_{37}$ Ibidem, s. 90.

38 APAN Oddz. w Poznaniu, Materialy prof. Heliodora Święcickiego, sygn. P - III - 85/10.

39 „Dziennik Poznański" 1923, nr 234 z dn. 13.X. 
w Poznaniu. Według raportu Jeziorowskiego z kwietnia 1808 roku, ,pierwszy seminarzysta wstapił do seminarium 2 lipca 1804 roku, inni - według kolejności zgłaszania się tak, że w styczniu następnego [1805] roku była już spełniona ilość 12 wychowanków (...). Otwarta została również szkółka wzorowa, dla wprawy młodych nauczycieli, w czerwcu 1805 roku"'. Rok przed tạ istotna w dziejach oświaty rocznica, 18 IX 2003 roku, Zarząd Główny Towarzystwa Historii Edukacji wyraził chęć jej uczczenia.

Postać, działalność i najważniejsze teksty Józefa Jeziorowskiego (1767-1845) od wielu już lat znane sa w literaturze przedmiotu. Jeziorowski urodził się na Śląsku Opolskim. Został katolickim księdzem. Studiował teologię we Wrocławiu. Po trzecim rozbiorze Polski przysłany został przez rząd pruski do Warszawy. Rzucił kapłaństwo i ożenił się. W 1801 roku władze pruskie przeniosły go do seminarium nauczycielskiego do Sulechowa ${ }^{2}$, gdzie został inspektorem seminarzystów polskiego pochodzenia. Tam spotkał Gotthilfa Samuela Steinbarta, członka pruskich władz oświatowych, profesora teologii Uniwersytetu we Frankfurcie nad Odra, rektora sulechowskiego zakładu opiekuńczo-wychowawczego (sierocińca, pedagogium i seminarium nauczycielskiego). W naszej literaturze przedmiotu w niedostatecznym, jak się wydaje, stopniu uwzględniano fakt, że pobyt Jeziorowskiego w Sulechowie (1801-1804) i kontakty ze Steinbartem zaważyły w bardzo dużym stopniu na formie seminarium nauczycielskiego w Poznaniu w latach 1804 - 1808. Koncentrowano się tylko na recepcji myśli Pestalozziego.

Tymczasem kilkuletni pobyt Jeziorowskiego w Sulechowie to bezpośrednie zetknięcie się z zakładem opiekuńczo-wychowawczym o tradycjach sięgających początku XVIII wieku i pietyzmu. Gotthilf (Gotthelf) Samuel Steinbart $(1738$-1809) był wnukiem Sigismunda (1677-1739) - ucznia Philippa Jacoba Spenera (1635-1705), twórcy pietyzmu (nurtu luteranizmu), teologa na Uniwersytecie w Halle. Głównym organizatorem i teoretykiem działalności pietystów na polu wychowania i kształcenia był - przypomnijmy - August Hermann Francke (1663-1727) - pastor, profesor teologii na Uniwersytecie w Halle i twórca zakładów wychowawczych w tym mieście (Franckesche Stiftungen). Jednym z naśladowców wzorów z Halle był wyżej wymieniony Sigismund Steinbart. W latach 1719-1721 założył on w Sulechowie sierociniec (Waisenhaus lub Orphanotropheum). Nie był on odosobniony. Na Pomorzu Zachodnim podobne pietystyczne sierocińce działały m.in. w Stargardzie (od 1696 roku, w drugiej połowie XVIII wieku szkoła realna z seminarium nauczycielskim) i w Szczecinie (1730 - 1732). Zwolennik pietyzmu, Johann Julius Hecker (1707-1768), uczeń Franckego, założył w Berlinie, w 1747 roku, ekonomiczno-matematyczną szkołę realną (Ökonomisch-Mathematische Realschule), wzór dla wielu szkół pruskich - w tym między innymi dla Sulechowa od 1766 roku. W 1767 roku kierownictwo nad szkolą i sierocińcem przejal Gotthilf Samuel Steinbart, od 1801 roku przełożony Jeziorowskiego. Również G.S. Steinbart studiował w młodości w Halle. Nadał on jednak placówce sulechowskiej wyraźnie nowe, już oświeceniowe oblicze. Większą wagę przywiązywał między innymi do problematyki świadomego przygotowania zawodowego nauczycieli. W $1766 \mathrm{r}$. Fryderyk II upaństwowił sulechowski ośrodek szkolnictwa elementarnego i podniósł go do rangi ośrodka ponadpodstawowego. Zmieniono także nazwę na Królewskie Pedagogium i Sierociniec w Sulechowie (Königliches Pädagogium und Waisenhaus zu Züllichau). Program szkół Steinbarta, dość typowy w owej epoce, obejmował naukę $\mathrm{o}$ administracji, o gospodarce, historię naturalna (przyrodoznawstwo) i polityczną, język ojczysty i języki nowożytne, matematykę z geometrią i ćwiczenia sportowe. Było to twórcze powtórzenie wzorca $z$ Halle i Berlina w warunkach Prus fryderykowskich. Z punktu widzenia rozwoju praktyki kształcenia nauczycieli bardzo istotne jest, że w Sulechowie łączono szkołę kształcaca w duchu oświeceniowym i wychowujaca przyszłych nauczycieli (szkoła ponadpodstawowa

${ }^{1}$ J. Jeziorowski, Doniesienie powszechności o urzadzeniu Seminarji Uczycielskiej Poznaniskiej..., Poznań, kwiecień 1808 . Tekst od 1808 roku do chwili obecnej nie był przedrukowywany, a ukazal się w wersji polskiej i niemieckiej $w$ dziesięciu zaledwie egzemplarzach, nakładem autora. Było to przyczyną skierowania przez piszącego te słowa do druku w księdze Pana Profesora Józefa Miąso (w druku) tego tekstu źródłowego, jak i jego obszerniejszego omówienia wraz z literatura przedmiotu. Niniejszy szkic jest jedynie wersja skróconą w.w. obszerniejszego omówienia.

${ }^{2}$ Miasto koło Zielonej Góry w dawnej Nowej Marchii (protestanckiej, poza granicami dawnej Rzeczypospolitej), niem. Züllichau, pol. dawniej również Cylichów. Jeziorowski stosuje na początku XIX wieku nazwę Żylichów. 
i seminarium nauczycielskie) z zakładem szkolno-wychowawczym dla dzieci. Teoria szkolna szła więc ściśle w parze z praktyka wychowawczo-opiekuńcza.

Tak więc, gdy w 1804 roku władze pruskie powierzyły Józefowi Jeziorowskiemu funkcję tworzenia seminarium nauczycielskiego w Poznaniu, był on do tego zadania dobrze przygotowany. $\mathrm{Z}$ jednej strony znał z praktyki zakład sulechowski (połączenie seminarium nauczycielskiego, szkoły średniej ogólnokształcącej, czyli pedagogium i zakładu opiekuńczo-wychowawczego dla dzieci) i tamtejsze, wywiedzione z ducha protestanckiego pietyzmu, a także pruskiego, fryderycjańskiego oświecenia, tradycje przygotowania zawodowego nauczycieli, z drugiej - doświadczenia metodyczne Pestalozziego w Burgdorfie ${ }^{3}$ i szkoly o tradycjach Philanthropin w Dessau. Znany, wielokrotnie publikowany i omawiany tekst Planu urzadzenia $w$ Poznaniu seminarium nauczycielów szkolnych (bakałarzy) $^{4} \mathrm{z}$ lutego 1804 roku można więc odczytywać nie tylko jako przykład twórczej recepcji w warunkach poznańskich poglądów Pestalozziego i Oliviera (z podróży w 1803 roku na polecenie władz pruskich), lecz również - a może przede wszystkim - wynik połączenia tych pogladów $z$ doświadczeniami sulechowskimi. Nie należy jednak popadać $w$ drugą skrajność. Znana jest krytyczna ocena Jeziorowskiego formułowana wobec steinbartowskiego seminarium nauczycielskiego w Sulechowje, zwłaszcza wobec przeładowanego programu zajęć (19 przedmiotów) ${ }^{5}$. Nie dochodzi więc w przypadku Jeziorowskiego do ,ślepej" recepcji, lecz raczej do (w miarę) twórczej interakcji.

Początki seminarium nauczycielskiego w Poznaniu były trudne. Umieszczono je w budynku klasztoru reformatów w Śródce, wówczas przedmieściu Poznania ${ }^{6}$. Klasztor reformatów sekularyzowany był przez władze pruskie w ramach szerszej akcji prowadzonej w tym samym czasie nie tylko w Wielkopolsce i na Śląsku?; nie tylko w protestanckich Prusach, lecz dokładnie w tym samym czasie również w katolickiej Badenii, Bawarii, Nadrenii. Józef Jeziorowski i nowo tworzone seminarium w Poznaniu znalazło się w samym centrum konfliktu. Nie bez znaczenia jest fakt, że Józef Jeziorowski, były katolicki ksiądz, z pomoca pruskiej policji musiał dla siebie i swej rodziny zdobyć pomieszczenie w dawnym katolickim klasztorze. Do niechęci społeczeństwa katolickiego wobec sekularyzacji klasztorów i umieszczania w nich przez świeckie władze państwowe między innymi - choć nie tylko - zakładów wychowawczych (analogicznie było w przypadku Pestalozziego w Stans!), w Poznaniu doszedł jeszcze do głosu element narodowy - Prusacy zamykali dawny polski klasztor. Władze pruskie przystosowały budynek klasztorny do celów seminarium nauczycielskiego. Już jednak w roku 1806, po wejściu Napoleona do Berlina i powstaniu wielkopolskim, budynek seminarium zajęły najpierw na lazaret wojska francuskie, a następnie polskie ${ }^{8}$. Seminarium przeniesiono do budynku Instytutu Akuszerskiego", gdzie panowały o wiele cięższe warunki: brak dużego ogrodu, wspólna sypialnia dla wszystkich seminarzystów itp. W 1809 roku władze oświatowe Księstwa Warszawskiego odwołały Jeziorowskiego z funkcji rektora seminarium. Jednocześnie pruskie władze oświatowe zaproponowały mu wysokie uposażenie (900 talarów rocznie) za objęcie funkcji rektora seminarium nauczycielskiego w Kwidzyniu ${ }^{10}$, a więc już poza granicami Ksjęstwa Warszawskiego. Seminarium powróciło do dawnego klasztoru OO. Reformatów w kwietniu 1810 roku. Tradycje oświatowe kontynuowane sa w tym budynku do dziś.

\footnotetext{
${ }^{3}$ Dodajmy, że poglądy Pestalozziego w 1803 roku, a więc gdy w Burgdorfie na kilka dni odwiedził go Jeziorowski, byly jeszcze nie do końca sprecyzowane, m.in. w dziedzinie formy kształcenia nauczycieli.

${ }^{4}$ Ostatnio w: Źródla do dziejów wychowania $i$ myśli pedagogicznej, oprac. S. Woloszyn, t. II, Kielce 1997, s. $292-302$.

${ }^{5}$ J. Enderówna, Jeziorowski, Józef [w:] PSB, t. 11, 221.

${ }^{6}$ Obecnie przy ul. Bydgoskiej 4b w Poznaniu. Budynek ten do dnia dzisiejszego zwiazany jest $z$ działalnościa oświatową. Mieści się tam obecnie Ośrodek Szkolno-Wychowawczy dla Dzieci Niestyszacych.

${ }^{7}$ P.P. Gach, Kasaty zakonów na ziemiach dawnej Rzeczypospolitej i Ślaska 1773-1914, Lublin 1984.

To też lączy Jeziorowskiego z Pestalozzim - w 1799 roku kilka pokoi w klasztorze kapucynek w Stans, gdzie znajdował sie zakład Pestalozziego, zajętych zostało przez francuski lazaret wojskowy.

${ }^{9}$ Czyli szkołę kształcąca położnych - znôw w duchu ścisłego łaczenia teorii z praktyką. Instytut Akuszerski, czyli Collegium medicum et sanitatis, niem. Hebammen-Lehranstalt, działał w latach $1799-1806$ i od 1810 do I wojny światowej. Obecnie - Zakład Opiekuńczo-Leczniczy, ul. Grobla 26 w Poznaniu.

${ }^{10}$ J. Ender, Jeziorowski, Józef [w:] PSB, t. 11, s. 221.
} 